\title{
Tyrosine kinases play a permissive role in glucose-induced insulin secretion from adult rat islets
}

\section{S J Persaud, T E Harris, C J Burns and P M Jones}

Cellular and Molecular Endocrinology Group, Biomedical Sciences Division, King's College London, Campden Hill Road, London W8 7AH, UK

(Requests for offprints should be addressed to S J Persaud)

\begin{abstract}
The role(s) played by protein tyrosine kinases (PTKs) in the regulation of insulin secretion from pancreatic $\beta$ cells is not clear. We have examined the effects of glucose, the major physiological insulin secretagogue, on the tyrosine phosphorylation state of islet proteins, and assessed $\beta$ cell insulin secretory responses in the presence of PTK inhibitors. Under basal conditions islets contained many proteins phosphorylated on tyrosine residues, and glucose (20 mM; 5-15 min) was without demonstrable effect on the pattern of tyrosine phosphorylation, in either the absence or presence of the protein tyrosine phosphatase (PTP) inhibitor, sodium pervanadate (PV). PV alone $(100 \mu \mathrm{M})$ increased tyrosine phosphorylation of several islet proteins. The PTK inhibitors genistein (GS) and tyrphostin A47
\end{abstract}

(TA47) inhibited islet tyrosine kinase activities and glucose-, $4 \alpha$ ketoisocaproic acid (KIC)- and sulphonylurea-stimulated insulin release, without affecting glucose metabolism. GS and TA47 also inhibited protein serine/threonine kinase activities to a limited extent, but had no effect on $\mathrm{Ca}^{2+}$, cyclic AMP - or phorbol myristate acetate (PMA)-induced insulin secretion from electrically permeabilised islets. These results suggest that PTK inhibitors exert their inhibitory effects on insulin secretion proximal to $\mathrm{Ca}^{2+}$ entry and it is proposed that they act at the site of the voltage-dependent $\mathrm{Ca}^{2+}$ channel which regulates $\mathrm{Ca}^{2+}$ influx into $\beta$ cells following nutrient- and sulphonylurea-induced depolarisation.

Fournal of Molecular Endocrinology (1999) 22, 19-28

\section{INTRODUCTION}

The intracellular mechanisms regulating insulin secretion from pancreatic $\beta$ cells are an active area of endocrine research and the roles played by serine/threonine protein kinases in this process have been studied extensively (reviewed by Persaud et al. 1994). However, much less is known about the involvement of protein tyrosine kinases (PTKs) in $\beta$ cell signal transduction processes, although a picture of PTKs present in islets and $\beta$ cells and some idea of the identities of their substrate proteins is beginning to emerge. Thus it is clear that $\beta$ cells of normal islets and $\beta$ cell lines express a number of receptor and cytoplasmic P'TKs (Öberg et al. 1994, Kanaka-Gantenbein et al. 1995, Öberg-Welsh \& Welsh 1995, Sorenson \& Stout 1995, Harbeck et al. 1996, Sekine et al. 1996) and several proteins which are known to play signal transduction roles in other cell types are phosphorylated on tyrosine residues in islets or $\beta$ cells (Rothenberg et al. 1995, Jonas \& Henquin 1996, Persaud et al. 1996, Sekine et al. 1996). There is convincing evidence that PTKs are important for $\beta$ cell differentiation from endocrine precursor cells, with reports of identification of particular PTKs in $\beta$ cells and growth of foetal pancreatic cells following their activation (Öberg et al. 1994, Kanaka-Gantenbein et al. 1995, Otonkoski et al. 1996).

However, there is not yet a clear consensus as to whether activation of PTKs modulates the insulin secretory response, nor to the intracellular sites of regulation by tyrosine phosphorylation. Some of the confusion may arise from the multiple pharmacological actions, unrelated to tyrosine kinase inhibition, of commonly used PTK inhibitors (Young et al. 1993). In a study using normal islets from adult rodents, genistein (GS) stimulated insulin secretion, but its inactive analogue, daidzein, produced similar effects, indicating a dissociation between PTK inhibition and stimulation of insulin secretion (Jonas et al. 1995). In the same study, tyrphostin A47 (TA47) significantly inhibited glucose-stimulated insulin secretion. Further 
confusion may arise from comparing responses of insulin-secreting cell lines and foetal or neonatal islets with those of adult islets containing fully differentiated $\beta$ cells, since the protein expression and secretory responses of proliferating $\beta$ cells may not always reflect the situation in normal adult islets. For example, a comparison of PTKs amplified from cDNAs from the RINm5F $\beta$ cell line, foetal islets and adult islets indicated that different PTKs were expressed in the different preparations (Öberg et al. 1994). In addition, studies using neonatal islets (Sorenson et al. 1994), MIN6 (Ohno et al. 1993) or insulin secreting cell line (INS-1) (Verspohl et al. 1995) $\beta$ cell lines have indicated that inhibition of PTKs with membrane permeant inhibitors enhances insulin release, perhaps suggestive of a tonic inhibitory role for PTKs on secretion from proliferating $\beta$ cells. In contrast, there has been one report, using the $\beta$ TC 3 cell line, that PTK inhibition causes inhibition of both tyrosine phosphorylation and insulin secretion in response to glucose and the cholinergic agonist carbachol (Konrad et al. 1996). The situation is further complicated by reports, using cell lines and neonatal and adult islets, that receptor-mediated activation of PTKs either stimulates (Brelje et al. 1994) or has no effect on (Sekine et al. 1996, Tazi et al. 1996) insulin release, while inhibition of protein tyrosine phosphatases (PTPs) has no effect on basal secretion and augments glucose-stimulated insulin release (Zhang et al. 1991, Persaud et al. 1996). These observations are inconsistent with a tonic inhibitory role for PTKs in insulin secretion. In light of this general confusion on the signalling roles of PTKs in the regulation of insulin secretion, we have now examined tyrosine phosphorylation and insulin secretory responses of normal adult islets, to determine the involvement of islet PTKs in the physiological secretory response of fully differentiated $\beta$ cells in adult rat islets of Langerhans.

\section{MATERIALS AND METHODS}

\section{Materials}

Collagenase (type XI), BSA (fraction V), hydrogen peroxide, dimethylthiazol-diphenyl tetrazolium bromide (MTT), glibenclamide, tolbutamide, phenyl methyl sulphonyl fluoride (PMSF), leupeptin, histone (type IIA and IIIS), myosin light chains, $4 \beta$ phorbol myristate acetate (PMA), cyclic AMP and isobutyl methylxanthine (IBMX) were purchased from Sigma Chemical Co. (Poole, Dorset, UK). GS, daidzein and TA47 and TA1 were obtained from Calbiochem (Beeston, Nottingham, UK).
Monoclonal anti-phosphotyrosine $\operatorname{IgG}$ was from Upstate Biotechnology Inc. (NY, USA) and goat anti-mouse IgG was obtained from Dako Ltd (High Wycombe, Bucks, UK). Enhanced chemiluminescence (ECL) reagents, Rainbow protein molecular weight markers and $\left[{ }^{125} \mathrm{I}\right]$ for insulin iodination were from Amersham International (Amersham, Bucks, $\mathrm{UK})$ and $\left[\gamma^{32} \mathrm{P}\right] \mathrm{ATP}(3000 \mathrm{Ci} / \mathrm{mmol})$ was from DuPont (UK) Ltd (Stevenage, Herts, UK). All other reagents were of analytical grade from $\mathrm{BDH}$ (Poole, Dorset, UK). Rats (Sprague-Dawley; 250g) were supplied by King's College London Animal Unit. The MIN6 $\beta$ cell line was kindly provided by Professor J I Miyazaki and Dr Y Oka (University of Tokyo, Japan).

\section{Insulin secretion}

Islets of Langerhans were isolated from rat pancreata by collagenase digestion as previously described (Jones et al. 1993), and for some experiments they were electrically permeabilised, in a buffer mimicking the intracellular environment, by exposure to a high intensity electric field (Jones et al. 1985). In static incubation secretion experiments, groups of three intact or five permeabilised islets were incubated for $1 \mathrm{~h}$ with secretagogues in the absence or presence of PTK inhibitors. The time-course of insulin secretory responses and the reversibility of the effects of TA47 were determined in a temperature-controlled $\left(37^{\circ} \mathrm{C}\right)$ perifusion system: groups of 40 intact islets were picked into perifusion chambers, and equilibrated for $30 \mathrm{~min}$ at a flow rate of $1 \mathrm{ml} / \mathrm{min}$ in a non-stimulatory physiological salt solution (Gey \& Gey 1936), after which fractions were collected every $2 \mathrm{~min}$ for analysis of insulin content. Immunoreactive insulin was measured in all experiments by radioimmunoassay as previously described (Jones et al. 1988).

\section{Immunological detection of tyrosine phosphorylated islet proteins}

Groups of $100-300$ islets or $1.5 \times 10^{6}$ MIN6 $\beta$ cells were incubated for $5-15 \mathrm{~min}$ at $37^{\circ} \mathrm{C}$ in the presence of 2 or $20 \mathrm{mM}$ glucose in the absence or presence of sodium pervanadate (PV) or PTK inhibitors. Islets or $\beta$ cells were pelleted, disrupted by sonication in gel electrophoresis sample buffer (Jones et al. 1988), and proteins were resolved on $10 \%$ polyacrylamide gels. Fractionated proteins were electrophoretically transferred onto $0 \cdot 2 \mu \mathrm{m}$ nitrocellulose membranes which were blocked overnight in phosphate buffered saline (PBS) supplemented with $0 \cdot 05 \%(\mathrm{v} / \mathrm{v})$ Tween 20 and $1 \%(\mathrm{w} / \mathrm{v}) \mathrm{BSA}$ and then incubated overnight in 
the presence of $1 \mu \mathrm{g} / \mathrm{ml}$ mouse monoclonal anti-phosphotyrosine antibody. Membranes were washed (4x15 min) in PBS/0.05\% (v/v) Tween-20 then incubated with peroxidase-conjugated goat anti-mouse IgGs $(250 \mathrm{ng} / \mathrm{ml})$ for $2 \mathrm{~h}$. Tyrosinephosphorylated proteins were detected by ECL following binding of the goat anti-mouse IgGs to the anti-phosphotyrosine antibody and their molecular masses were determined from a calibration curve constructed from the migration positions of coloured protein molecular mass markers.

\section{Islet glucose metabolism}

The effects of PTK inhibitors on glucose metabolism were determined by the MTT colorimetric assay in which the rate of MTT reduction to formazan crystals correlates with glucose oxidation and glucose utilisation (Jancic \& Wollheim 1992). Groups of 10 islets were picked into wells of microtitre plates, preincubated for $1 \mathrm{~h}$ in the absence of MTT, then for a further hour with $1 \mathrm{mg} / \mathrm{ml} \mathrm{MTT}$ at 2 or $20 \mathrm{mM}$ glucose in the absence or presence of GS or TA47. Formazan crystals were solubilised in isopropanol and the optical density was recorded with an automated plate reader at $570 \mathrm{~nm}$. Changes in background absorbance, in the absence of islets, were corrected for by subtraction from the appropriate optical density values obtained in the presence of islets.

\section{Measurement of effects of PTK inhibitors on islet serine/threonine kinase activities}

For measurement of protein kinase $\mathrm{C}$ (PKC), protein kinase A (PKA) and $\mathrm{Ca}^{2+} /$ calmodulindependent protein kinase (CaMK) activities, islets were resuspended in a lysis buffer $(20 \mathrm{mM}$ Tris/ $\mathrm{HCl} \quad(\mathrm{pH} \quad 7 \cdot 4), 2 \mathrm{mM}$ EDTA, $0.5 \mathrm{mM}$ EGTA, $50 \mu \mathrm{g} / \mathrm{ml}$ leupeptin, $1 \mathrm{mM}$ PMSF and $0 \cdot 1 \%(\mathrm{v} / \mathrm{v}) 2$-mercaptoethanol) and disrupted by sonication (MSE Soniprobe, 3x15 s, $6 \mu$ ). PKA and CaMK activities of sonicated islet extracts were measured in the presence of appropriate activators and substrates $(100 \mu \mathrm{M}$ cyclic AMP, $100 \mu \mathrm{M}$ IBMX, $1 \mathrm{mg} / \mathrm{ml}$ histone IIA and $50 \mu \mathrm{g} / \mathrm{ml}$ calmodulin, $0.5 \mathrm{mM} \mathrm{CaCl} 2,1 \mathrm{mg} / \mathrm{ml}$ myosin light chains respectively) and $100 \mu \mathrm{M}\left[\gamma^{32} \mathrm{P}\right] \mathrm{ATP}$ as previously described (Persaud \& Jones 1995). For measurement of islet PKC activity, PKC was partially purified from sonicated islet extracts by anion exchange chromatography and ${ }^{32} \mathrm{P}$ incorporation into histone IIIS $(1 \mathrm{mg} / \mathrm{ml})$ was determined in the presence of $96 \mu \mathrm{g} / \mathrm{ml}$ phosphatidylserine, $6.4 \mu \mathrm{g} / \mathrm{ml}$ diolein and $1.3 \mathrm{mM} \mathrm{CaCl}_{2}$ (Persaud \& Jones 1995).

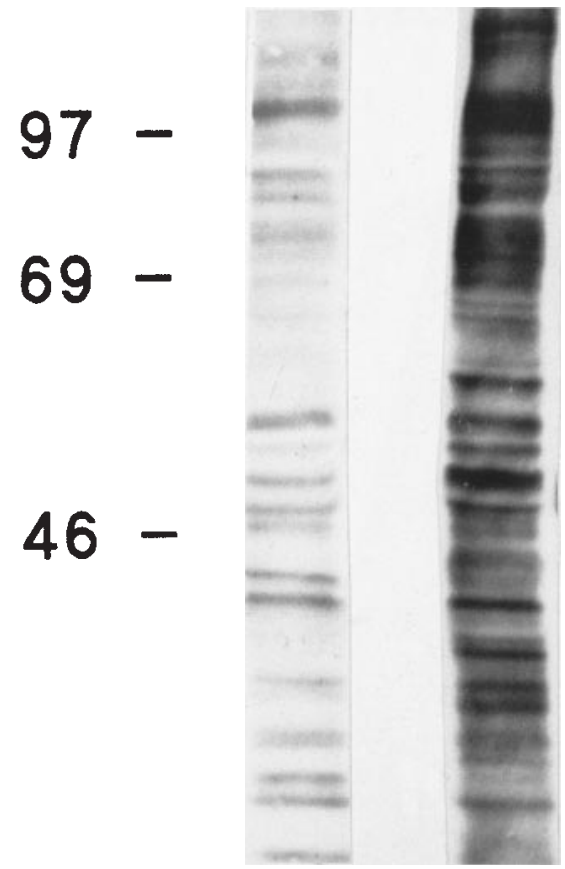

FIGURE 1. Immunological detection of tyrosinephosphorylated islet proteins. Groups of 300 (left lane) or 100 (right lane) islets were incubated for $5 \mathrm{~min}$ in the absence (left lane) or presence (right lane) of $100 \mu \mathrm{M}$ of the PTP inhibitor, PV. Islet proteins were separated on $10 \%$ gels and tyrosine phosphorylated proteins were detected by immunoblotting. Numbers indicate migration positions of molecular mass markers (kDa). Results are representative of three separate experiments.

\section{Statistical analysis}

Results are presented, where appropriate, as means \pm S.E.M. for the number of observations as indicated. Statistical significance was determined by one way analysis of variance, followed by Bonferroni's multiple comparisons test where necessary. All other data were analysed by Student's $t$-tests or by Welch's $t$-tests for data means with different standard deviations. Differences between experimental and control samples were considered significant at $P<0 \cdot 05$.

\section{RESULTS}

\section{Tyrosine phosphorylation of islet proteins}

Under non-stimulatory conditions (2 mM glucose), islets expressed several tyrosine kinase substrates, the most notable of which had approximate molecular masses of $33,34,42,44,48,51,55,90$ and $112 \mathrm{kDa}$ (Fig. 1, left lane). Exposure of islets 

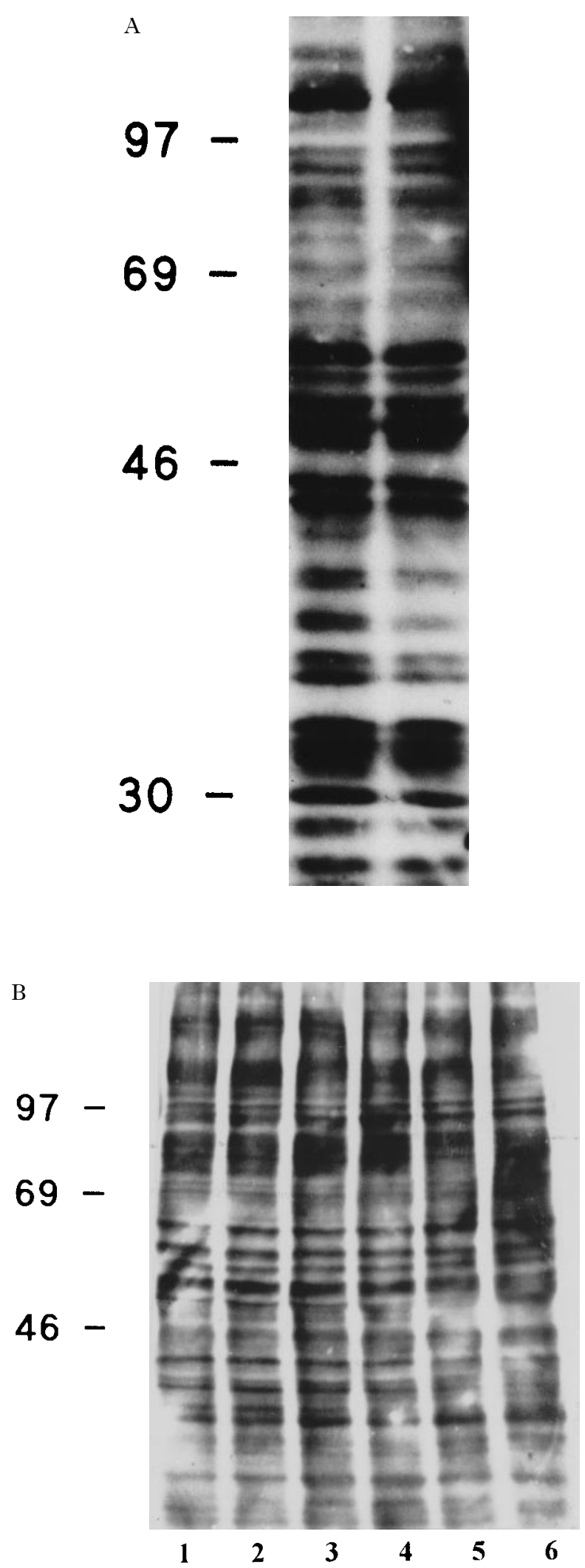

to the PTP inhibitor, PV $(100 \mu \mathrm{M})$, resulted in an overall increase in tyrosine phosphorylation, together with the appearance of some novel tyrosinephosphorylated substrates (Fig. 1, right lane; increased phosphorylation of proteins of approximate molecular masses of $36,37,39,42,51,55,59$, $72-85,115-125$ and $145 \mathrm{kDa})$. Although PV caused marked increases in the phosphotyrosine content of unstimulated islets, its effects on insulin secretion were minimal: in only one of three experiments did it significantly stimulate secretion $(2 \mathrm{mM}$ glucose: $0.23 \pm 0.05 \mathrm{ng} /$ islet $/ \mathrm{h} ; 2 \mathrm{mM}$ glucose $+100 \mu \mathrm{M} \mathrm{PV}$ : $0.58 \pm 0.07, P<0.01, n=7)$, and the secretory response was considerably less than that stimulated by $20 \mathrm{mM}$ glucose in the same experiment $(7 \cdot 30 \pm$ $0.63 \mathrm{ng} /$ islet $/ \mathrm{h})$. When islets were exposed to $20 \mathrm{mM}$ glucose for $15 \mathrm{~min}$, the profile of tyrosine phosphorylated proteins was not detectably different from that seen in the presence of $2 \mathrm{mM}$ glucose (Fig. 2A). In similar experiments, carried out in the presence of $100 \mu \mathrm{M}$ PV to inhibit PTPs, $20 \mathrm{mM}$ glucose was without marked effect on the tyrosine phosphorylation state of islet proteins when determined after 5, 10 and 15 min exposure (Fig. 2B).

\section{Effects of tyrosine kinase inhibitors on insulin secretion}

The lack of effect of glucose on tyrosine phosphorylation, together with the dissociation between the large effects of PV on phosphotyrosine content of islet proteins and its small effects on insulin secretion, make it difficult to draw conclusions about the requirement for signalling through PTK pathways for insulin secretion based on measurements of tyrosine phosphorylation alone. The effects of pharmacological modulation of PTK activities on islet and $\beta$ cell secretory responses to insulin secretagogues were therefore examined. Table 1 shows that two structurally dissimilar

FIGURE 2. Effect of glucose on islet PTK activities. The figure shows tyrosine phosphorylated islet proteins and the numbers indicate the migration positions of molecular mass markers $(\mathrm{kDa})$. Results are representative of four separate experiments. (A) Groups of 300 islets were incubated for $15 \mathrm{~min}$ in the presence of $2 \mathrm{mM}$ (left lane) or $20 \mathrm{mM}$ (right lane) glucose.

(B) Groups of 100 islets (lanes 1-4) or 50 islets (lanes 5 and 6) were incubated for 5 (lanes 1 and 2), 10 (lanes 3 and 4) or 15 (lanes 5 and 6) $\mathrm{min}$ in the presence of $2 \mathrm{mM}$ glucose (lanes 1, 3 and 5) or $20 \mathrm{mM}$ (lanes 2, 4 and 6) glucose. All incubations were carried out in the presence of $100 \mu \mathrm{M} \mathrm{PV}$. 
TABLE 1. Effects of P'TK inhibitors on glucosestimulated insulin secretion. Intact islets were incubated for $1 \mathrm{~h}$ at $2 \mathrm{mM}$ glucose or at $20 \mathrm{mM}$ glucose \pm PTK inhibitors or their inactive analogues and insulin secretion was measured by radioimmunoassay. Data are taken from four independent experiments, each of 8-9 observations and secretion is expressed as a percentage of stimulated $(20 \mathrm{mM})$ insulin secretion. From the four experiments, mean insulin secretion at $2 \mathrm{mM}$ glucose was $0 \cdot 10 \pm 0 \cdot 009 \mathrm{ng} /$ islet/h and at $20 \mathrm{mM}$ glucose it was $2 \cdot 82 \pm 0 \cdot 32 \mathrm{ng} /$ islet $/ \mathrm{h}$

\begin{tabular}{lc} 
& $\begin{array}{l}\text { Insulin secretion } \\
\text { (\% glucose-stimulated) }\end{array}$ \\
\cline { 2 - 2 } Treatment & $136 \pm 7^{\mathrm{a}}$ \\
$50 \mu \mathrm{M}$ genistein & $96 \pm 12$ \\
$100 \mu \mathrm{M}$ genistein & $34 \pm 4^{\mathrm{b}}$ \\
$200 \mu \mathrm{M}$ genistein & $3 \pm 3^{\mathrm{b}}$ \\
$500 \mu \mathrm{M}$ genistein & $80 \pm 6^{\mathrm{a}}$ \\
$500 \mu \mathrm{M}$ daidzein & $74 \pm 3^{\mathrm{a}}$ \\
$12 \cdot 5 \mu \mathrm{M}$ TA47 & $40 \pm 4^{\mathrm{b}}$ \\
$25 \mu \mathrm{M}$ TA47 & $48 \pm 6^{\mathrm{b}}$ \\
$50 \mu \mathrm{M}$ TA47 & $5 \pm 1^{\mathrm{b}}$ \\
$100 \mu \mathrm{M}$ TA47 & $98 \pm 8$ \\
$200 \mu \mathrm{M}$ TA47 & $141 \pm 17^{\mathrm{a}}$ \\
$12 \cdot 5 \mu \mathrm{M}$ TA1 & $143 \pm 10^{\mathrm{a}}$ \\
$25 \mu \mathrm{M}$ TA1 & \\
$50 \mu \mathrm{M}$ TA1 &
\end{tabular}

${ }^{\mathrm{a}} P<0 \cdot 05,{ }^{\mathrm{b}} P<0 \cdot 0001$ versus secretion at $20 \mathrm{mM}$ glucose.

inhibitors of PTKs, GS and TA47, both caused dose-related inhibition of glucose-stimulated insulin secretion, such that at the highest concentrations used, secretion was not significantly different from that obtained at a substimulatory concentration of glucose $(2 \mathrm{mM})$. GS $(50 \mu \mathrm{M})$ caused a small, but significant, potentiation of glucose-stimulated secretion, but at concentrations of GS greater than $100 \mu \mathrm{M}$, secretion was significantly inhibited. The inactive analogue of GS, daidzein, was without effect on insulin release when used at a concentration $(500 \mu \mathrm{M})$ at which GS fully inhibited glucose-stimulated secretion. Similar effects were obtained with TA47, which was a more potent inhibitor of glucose-induced insulin release, causing maximal inhibition at $200 \mu \mathrm{M}$. The inactive analogue of TA47, TA1, did not inhibit secretion, but low concentrations ( 25 and $50 \mu \mathrm{M})$ significantly potentiated the response to glucose (Table 1). Pretreatment of islets with $100 \mu \mathrm{M} \mathrm{PV}$ for $10 \mathrm{~min}$, to inactivate PTPs, did not significantly affect the inhibition of secretion caused by GS and TA47 $(20 \mathrm{mM}$ glucose: $5.42 \mathrm{ng} /$ islet $/ \mathrm{h} ; \quad+500 \mu \mathrm{M}$ GS: $0 \cdot 41 \pm 0 \cdot 08 ;+100 \mu \mathrm{M}$ PV $+500 \mu \mathrm{M}$ GS: $0 \cdot 55 \pm 0 \cdot 16$; $+200 \mu \mathrm{M}$ TA47: $0 \cdot 17 \pm 0 \cdot 05 ;+100 \mu \mathrm{M} \mathrm{PV}+200 \mu \mathrm{M}$ TA47: $0 \cdot 30 \pm 0 \cdot 08, n=9$, all $P<0 \cdot 001$ versus $20 \mathrm{mM}$ glucose). The maximal inhibitory concentrations of GS and TA47 also fully inhibited insulin secretion in response to $4 \alpha$ ketoisocaproic acid (KIC), a leucine metabolite $(2 \mathrm{mM}$ glucose: $0.23 \pm 0.05 \mathrm{ng} /$ islet $/ \mathrm{h} ; 10 \mathrm{mM} \quad$ KIC: $3.79 \pm 0.35$; $10 \mathrm{mM} \quad$ KIC $+500 \mu \mathrm{M} \quad$ GS: $0 \cdot 31 \pm 0 \cdot 02 ; 10 \mathrm{mM}$ $\mathrm{KIC}+200 \mu \mathrm{M}$ TA47: $0 \cdot 45 \pm 0 \cdot 09, n=7-8, P<0 \cdot 001$ versus $10 \mathrm{mM} \mathrm{KIC}$ ).

The inhibition of insulin secretion from islets did not result from irreversible damage to the $\beta$ cells since the effects were fully reversible. It can be seen from the perifusion experiments shown in Fig. 3A that the inhibitory effect of TA47 was rapid in onset and full inhibition of the secretory response to $20 \mathrm{mM}$ glucose was achieved within $20 \mathrm{~min}$. In addition, the TA47-induced inhibition was rapidly reversible upon its removal (Fig. 3B). Thus, in the presence of $20 \mathrm{mM}$ glucose and $200 \mu \mathrm{M}$ TA47, secretion was only marginally higher than basal (min 10-30 versus $0-10$ ), but replacement of the medium with $20 \mathrm{mM}$ glucose alone ( $\min 30-50$ ) resulted in the expected rapid and biphasic secretory response.

Since glucose-stimulated insulin secretion is dependent on metabolism of glucose, and PTK inhibitors have been shown to inhibit metabolic enzymes (Young et al. 1993), it is possible that the inhibitory effects of GS and TA47 on glucosestimulated insulin release could reflect inhibition of glucose metabolism. However, using the MTT assay which has been established for assessing glucose metabolism in insulin-secreting cells (Jancic \& Wollheim 1992), neither GS nor TA47 significantly affected glucose-stimulated formazan production from MTT (2 mM glucose: 0.068 \pm 0.009 absorbance units; $20 \mathrm{mM}$ glucose: $0 \cdot 271 \pm 0 \cdot 026$; $+500 \mu \mathrm{M} \quad$ GS: $0 \cdot 298 \pm 0 \cdot 007 ;+200 \mu \mathrm{M}$ TA47: $0 \cdot 255 \pm 0 \cdot 004, n=5, P>0 \cdot 2$ versus $20 \mathrm{mM}$ glucose for GS and TA47). In addition, GS and TA47 also inhibited insulin secretion in response to the sulphonylureas tolbutamide and glibenclamide, which stimulate insulin release by inhibiting ATP-sensitive $\mathrm{K}^{+}$channels. A maximal inhibitory concentration of GS fully inhibited tolbutamideand glibenclamide-stimulated secretion at a threshold stimulatory concentration of glucose $(5 \mathrm{mM})$, while TA47 caused a significant, but incomplete, inhibition of secretion in response to the sulphonylureas $(200 \mu \mathrm{M}$ tolbutamide: $628 \pm$ $100 \%$ secretion at $5 \mathrm{mM}$ glucose; $+500 \mu \mathrm{M}$ GS: $86 \pm 14 \% ; \quad+200 \mu \mathrm{M} \quad \mathrm{TA} 47: \quad 271 \pm 51 \% ; \quad 10 \mu \mathrm{M}$ glibenclamide: $528 \pm 71 \%$ secretion at $5 \mathrm{mM}$ glucose; $+500 \mu \mathrm{M}$ GS: $157 \pm 37 \%$; $+200 \mu \mathrm{M}$ TA47: $271 \pm 66 \%, n=9, P<0.05$ for both PTK inhibitors). Under the same experimental conditions GS inhibited $20 \mathrm{mM}$ glucose-stimulated insulin secretion to basal levels while there was still a small residual response in the presence of TA47 $(5 \mathrm{mM}$ 

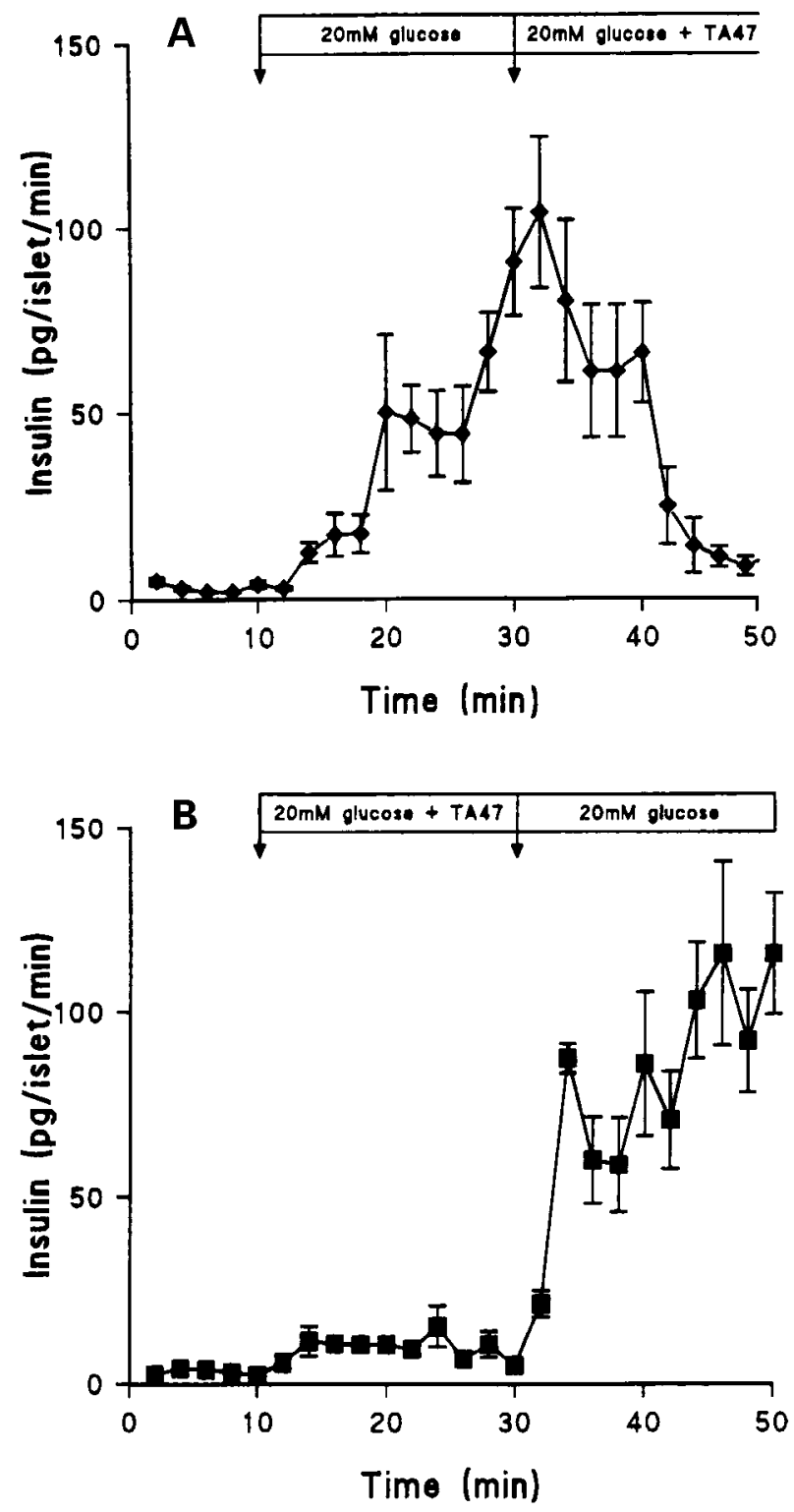

FIGURE 3. Time-course and reversibility of the inhibition of glucose-stimulated insulin secretion by TA47. Islets were perifused with $2 \mathrm{mM}$ glucose for $30 \mathrm{~min}$ before the start of the experiments and basal secretion measured over the last $10 \mathrm{~min}$ is shown in both panels A and B (at min 0-10). Arrows indicate times at which perifusion media were changed as shown. Data for each panel are mean secretion ( \pm s.E.M.) from four separate groups of islets. (A) At $\min 10-30: 20 \mathrm{mM}$ glucose; $\min$ 30-50: $20 \mathrm{mM}$ glucose+200 $\mu \mathrm{M}$ TA47. (B) At min10-30: $20 \mathrm{mM}$ glucose $+200 \mu \mathrm{M}$ TA47; min 30-50: $20 \mathrm{mM}$ glucose.

glucose: $\quad 0 \cdot 07 \pm 0 \cdot 01 \mathrm{ng} /$ islet $/ \mathrm{h} ; \quad 20 \mathrm{mM}$ glucose: $2 \cdot 57 \pm 0 \cdot 31 ; \quad+500 \mu \mathrm{M}$ GS: $0 \cdot 12 \pm 0 \cdot 02 ; \quad+200 \mu \mathrm{M}$ TA47: $0 \cdot 32 \pm 0 \cdot 02)$.
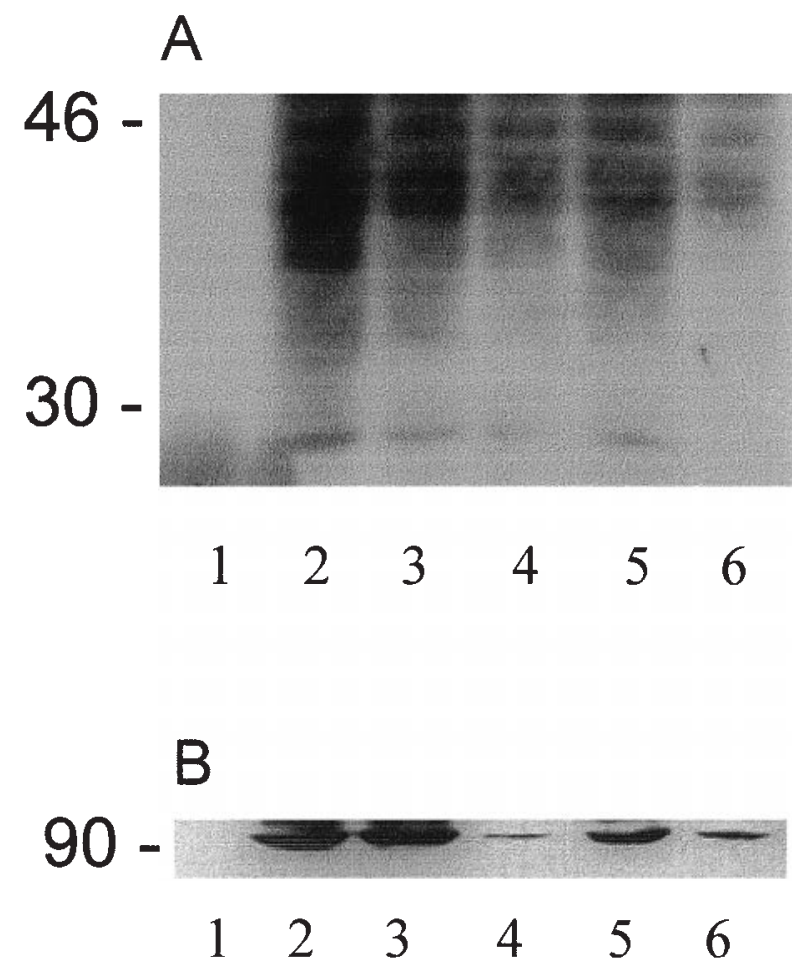

FIGURE 4. Inhibition of PTK activities by GS and TA47. The figure shows tyrosine phosphorylated islet (panel A) and MIN6 $\beta$ cell (panel B) proteins, detected as described in Materials and Methods. The numbers indicate molecular masses $(\mathrm{kDa})$. Results are representative of four separate experiments. Treatments were the same for islets (200 islets/lane) and MIN6 cells (120 $\mu \mathrm{g}$ protein/lane), with incubations being performed in the absence of PV (lane 1) or in the presence of $100 \mu \mathrm{M} \mathrm{PV}$ (lanes 2-6). Lane 1: $2 \mathrm{mM}$ glucose; lane 2: $2 \mathrm{mM}$ glucose; lane 3: $2 \mathrm{mM}$ glucose $+200 \mu \mathrm{M}$ GS; lane 4: $2 \mathrm{mM}$ glucose $+500 \mu \mathrm{M}$ GS; lane 5: $2 \mathrm{mM}$ glucose $+50 \mu \mathrm{M}$ TA47; lane $6: 2 \mathrm{mM}$ glucose $+200 \mu \mathrm{M}$ TA47.

\section{Effects of tyrosine kinase inhibitors on islet tyrosine kinase and serine/threonine kinase activities}

The effects of TA47 and GS on tyrosine phosphorylation of endogenous islet proteins was examined by treating islets for $5 \mathrm{~min}$ with $\mathrm{GS}$ and TA47 at concentrations which partially $(200 \mu \mathrm{M}$ GS, $50 \mu \mathrm{M}$ TA47) or maximally $(500 \mu \mathrm{M}$ GS, $200 \mu \mathrm{M}$ TA47) inhibited insulin secretion. It can be seen from Fig. 4A that inclusion of $100 \mu \mathrm{M}$ PV led to marked increases in the tyrosine phosphorylation state of numerous proteins (lane 2 versus lane 1 ), and that exposure to either GS or TA47 for $5 \mathrm{~min}$ 
caused a concentration-dependent decrease in the phosphotyrosine content of several of these proteins, with the effects of TA47 (lanes 5 and 6) being more marked than those of GS (lanes 3 and 4). The high level of tyrosine phosphorylation obtained in the presence of PV obscures, to a certain extent, the inhibitory effects of the PTK inhibitors on the phosphorylation of individual $\beta$ cell proteins, but it can be seen clearly from Fig. 4B that a $90 \mathrm{kDa}$ $\beta$ cell PTK substrate was almost completely dephosphorylated in the presence of $500 \mu \mathrm{M}$ GS (lane 4) or $200 \mu \mathrm{M}$ TA47 (lane 6). Although GS and TA47 clearly inhibited $\beta$ cell PTK activities, the concentrations required for this and for full inhibition of glucose-stimulated insulin secretion were relatively high and it is known that high concentrations of both compounds may inhibit serine/threonine kinases (O’Dell et al. 1991). To address this possibility, the effects of GS and TA47 on islet PKC, PKA and CaMK activities in vitro were assessed. Both GS and TA47 significantly inhibited islet PKC activity (control: $128 \pm$ $3 \cdot 8 \mathrm{fmol} /$ islet $/ \mathrm{min}$; $+500 \mu \mathrm{M} \mathrm{GS}: 68 \pm 4 \cdot 2 ;+200 \mu \mathrm{M}$ TA47: $51 \pm 1 \cdot 2, n=4$ ), while TA47, but not GS, inhibited PKA activity (control: $70 \pm 1.9 \mathrm{fmol} /$ islet/ $\min ; \quad+500 \mu \mathrm{M}$ GS: $74 \pm 0 \cdot 9 ;+200 \mu \mathrm{M}$ TA47: $32 \pm 0 \cdot 6, n=4)$. In both instances, the inhibitory effects of GS and TA47 were partial. In the CaMK assay, $\mathrm{Ca}^{2+}$ and calmodulin stimulated the phosphorylation of both exogenous myosin light chains and endogenous islet proteins of molecular masses ranging from 33 to $60 \mathrm{kDa}$ (Fig. 5). In the presence of $500 \mu \mathrm{M} \mathrm{GS}$, islet CaMK activity was not noticeably affected, but $200 \mu \mathrm{M}$ TA47 caused a marked decrease in phosphorylation of both exogenous and endogenous substrates. Again, although profound, the inhibitory effect of TA47 was not complete, as phosphorylation in its presence was still greater than that obtained in the absence of $\mathrm{Ca}^{2+}$ and calmodulin. In particular, phosphorylation of the $57-60 \mathrm{kDa}$ substrates, which may reflect autophosphorylation of endogenous CaMK, was still greatly enhanced.

\section{Effects of tyrosine kinase inhibitors on insulin secretion from electrically permeabilised islets}

Insulin secretion from electrically permeabilised islets was stimulated by direct activation of PKC, PKA and CaMK by PMA, cyclic AMP and $\mathrm{Ca}^{2+}$ respectively (Table 2). The responses to these agents were not inhibited by GS or TA47, when used at concentrations which fully inhibited glucose-stimulated insulin secretion.

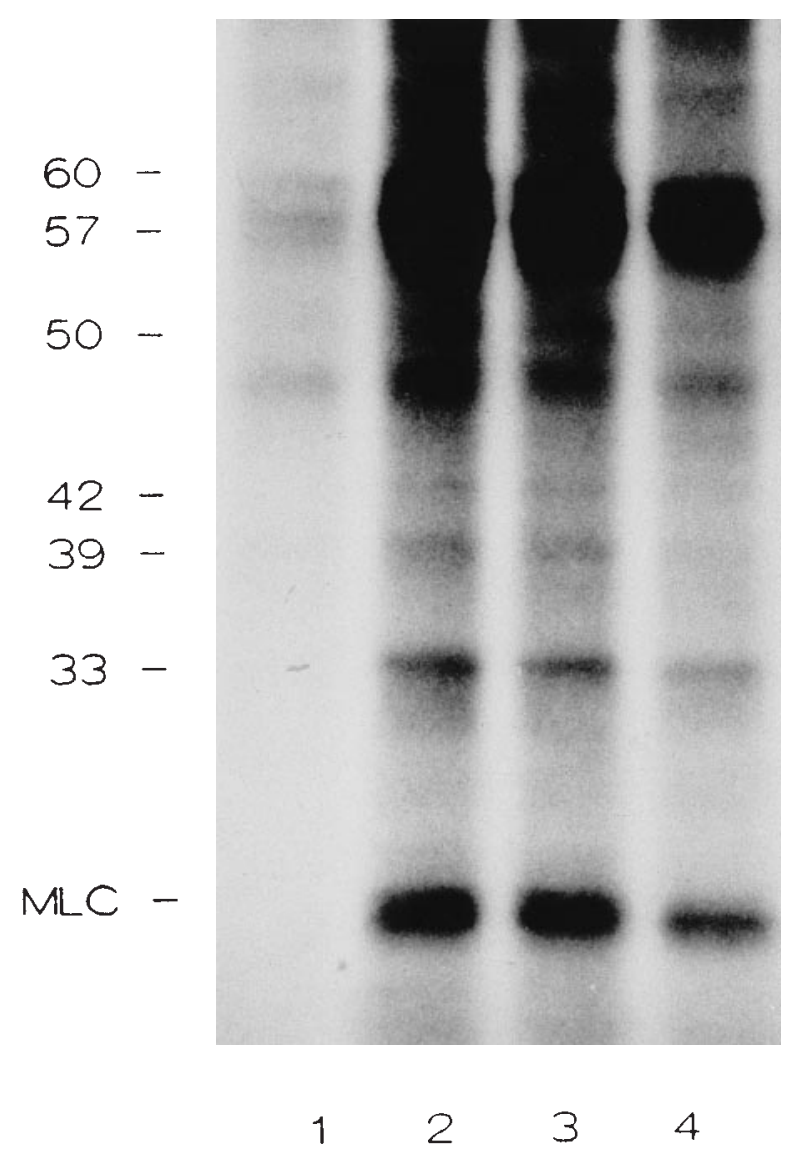

FIGURE 5. Effects of GS and TA47 on islet $\mathrm{Ca}^{2+} /$ calmodulin-dependent kinase activity. The figure shows an autoradiograph of ${ }^{32} \mathrm{P}$ incorporation into islet proteins in the absence (lane 1) or presence (lanes 2-4) of $\mathrm{Ca}^{2+}$ and calmodulin. Islet extracts were incubated for $10 \mathrm{~min}$ in the absence of TK inhibitors (lanes 1 and 2) or in the presence of $500 \mu \mathrm{M}$ GS (lane 3) or $200 \mu \mathrm{M}$ TA47 (lane 4). Numbers indicate the molecular masses $(\mathrm{kDa})$ of some endogenous islet proteins which showed $\mathrm{Ca}^{2+}$ /calmodulin-dependent phosphorylation, and MLC indicates phosphorylation of exogenous myosin light chains.

\section{DISCUSSION}

In the present study, the importance of PTKmediated signalling pathways in the rapid insulin secretory events of pancreatic $\beta$ cells has been examined. It is clear that PTK/PTP signal transduction systems are active in unstimulated islets since, in the absence of exogenous stimuli, numerous tyrosine-phosphorylated proteins were identified and inhibition of PTPs with PV caused a marked increase in the tyrosine phosphorylation state of many islet proteins, indicative of a rapid 
TABLE 2. Effects of TA47 and GS on insulin secretion from electrically permeabilised islets. Islets were permeabilised, incubated for $1 \mathrm{~h}$ as below and insulin secretion was determined by radioimmunoassay. The effect of cyclic AMP and PMA were determined in the presence of $50 \mathrm{nM} \mathrm{Ca}^{2+}$. Insulin secretion is expressed as $\mathrm{pg} /$ islet/h ( \pm s.E.M.), and the numbers of observations are shown in parentheses

Insulin secretion (pg/islet/h)

\section{Treatment \\ $50 \mathrm{nM} \mathrm{Ca}^{2+}$ \\ $10 \mu \mathrm{M} \mathrm{Ca}^{2+}$ \\ $10 \mu \mathrm{M} \mathrm{Ca}{ }^{2+}+200 \mu \mathrm{M} \mathrm{TA} 47$ \\ $10 \mu \mathrm{M} \mathrm{Ca}{ }^{2+}+500 \mu \mathrm{M}$ GS \\ $500 \mu \mathrm{M}$ cyclic AMP \\ $500 \mu \mathrm{M}$ cyclic AMP $+200 \mu \mathrm{M}$ TA47 \\ $500 \mu \mathrm{M}$ cyclic AMP $+500 \mu \mathrm{M}$ GS \\ 500 nM PMA \\ 500 nM PMA $+200 \mu \mathrm{M}$ TA47 \\ $500 \mathrm{nM}$ PMA $+500 \mu \mathrm{M}$ GS}

${ }^{\mathrm{a}} \mathrm{P}<0 \cdot 0001$ versus secretion at $50 \mathrm{nM} \mathrm{Ca}{ }^{2+},{ }^{\mathrm{b}} \mathrm{P}>0 \cdot 1$ versus appropriate control in absence of PTK inhibitor.

phosphorylation/dephosphorylation cycle of tyrosine residues. It has been reported recently that exposure of mouse islets to vanadate for $15 \mathrm{~min}$ resulted in enhanced tyrosine phosphorylation of proteins of molecular masses 60, 74, 79, 85 110, 117 125,145 and $165 \mathrm{kDa}$ (Jonas \& Henquin 1996) and these observations fit in well with the findings of the present study, in which proteins of similar molecular masses, and some of lower molecular masses, showed increased phosphorylation on tyrosine residues following inhibition of PTPs. However, in the current experiments there were no marked glucose-dependent changes in the tyrosine phosphorylation state of islet PTK substrates, in keeping with an earlier report that glucoseresponsive tyrosine phosphorylation is absent in islets (Rothenberg et al. 1995). Although it is impossible to rule out glucose-induced changes in the phosphotyrosine content of minority substrates, the dissociation between the large increases in tyrosine phosphorylation in response to PV and its small effects on insulin secretion suggest that it is difficult to define a role for PTKs in the regulation of insulin release from measurements of changes in tyrosine phosphorylation alone.

A complementary approach, that of measurement of the insulin-secretory capacity of islets and $\beta$ cells in the presence of PTK inhibitors, has been reported previously by several groups (Ohno et al. 1993, Sorenson et al. 1994, Jonas et al. 1995, Verspohl et al. 1995). In the present study, $50 \mu \mathrm{M}$ GS significantly potentiated glucose-stimulated

insulin release from rat islets, as did low concentrations of the inactive analogue of TA47, TA1, but higher concentrations of GS and all concentrations of TA47 were inhibitory. Two earlier reports (Ohno et al. 1993, Jonas et al. 1995) have suggested that the stimulatory effects of GS on insulin secretion may occur independently of PTK inhibition, and it is possible that GS-induced increases in cyclic AMP (Ohno et al. 1993) may account for the potentiation of insulin secretion seen at low concentrations of this PTK inhibitor, but that this stimulatory effect is masked by PTK inhibition at higher concentrations of GS. Our data indicate that high concentrations of PTK inhibitors are required to inhibit tyrosine phosphorylation of endogenous proteins, and suggest that the true and consistent effect of inhibition of PTKs in adult rat islets is an inhibition of glucose-stimulated insulin secretion. The inhibitory effect of $100 \mu \mathrm{M}$ TA47 in the present studies was identical to that reported previously for mouse islets (Jonas et al. 1995) and perifusion studies confirmed that TA47 causes a rapid and reversible inhibition of secretion in response to $20 \mathrm{mM}$ glucose. Examination of the effects PTK inhibitors on serine/threonine kinases indicated that GS and TA47 were also able to inhibit islet PKC, PKA and CaMK activities to varying extents. TA47 was the more promiscuous inhibitor, causing marked, but incomplete, inhibition of all three kinases. GS inhibited islet PKC activity, without affecting activities of PKA and CaMK. The partial inhibitory effects of PTK inhibitors on serine/threonine kinase activities was insufficient to inhibit secretion in response to activators of these kinases, as the secretory responses of electrically permeabilised islets to $\mathrm{Ca}^{2+}, \mathrm{PMA}$ and cyclic AMP were not affected by the presence of PTK inhibitors. Nor can the inhibition of glucosestimulated insulin release be explained by the inhibitory effects of the PTK inhibitors on serine/ threonine kinases, as the common inhibitory effect of GS and TA47 was on islet diacylglycerol-sensitive PKC activity, but this would not be expected to fully inhibit glucose-induced insulin release (reviewed by Persaud et al. 1992).

The inhibitory effects of the PTK inhibitors on insulin secretion could not be ascribed to inhibition of glucose metabolism, because they also inhibited secretion stimulated by KIC, which acts distal to glycolysis, and glucose-stimulated formazan production, an index of glucose oxidation and utilisation, was not affected by GS or TA47. Both inhibitors also significantly reduced tolbutamideand glibenclamide-induced insulin release at a threshold stimulatory concentration of glucose. These results give an indication of the site of action 
of PTK inhibitors on the insulin secretory process. Since they inhibited glucose-, KIC- and sulphonylurea-stimulated insulin release, but not $\mathrm{Ca}^{2+}$-induced secretion, it is clear that GS and TA47 exert their effects distal to closure of ATP-sensitive $\mathrm{K}^{+}$channels, but proximal to increases in intracellular $\mathrm{Ca}^{2+}$. A site of action at the voltage-dependent $\mathrm{Ca}^{2+}$ channel (VDCC) would be consistent with these data, and a previous report indicated that GS reversibly inhibited voltageactivated $\mathrm{Ca}^{2+}$ currents in $\beta$ cells from adult mouse islets (Jonas et al. 1995). The mode of action of GS on blockade of $\beta$ cell $\mathrm{Ca}^{2+}$ channels has not been established, but since we have found that two structurally dissimilar PTK inhibitors inhibited insulin secretion at a site proximal to increased $\mathrm{Ca}^{2+}$ levels, it is likely that they block the channels as a consequence of PTK inhibition rather than by a physical inhibition of $\mathrm{Ca}^{2+}$ influx. The likelihood of a non-physical interaction of the PTK inhibitors with $\mathrm{Ca}^{2+}$ channels is supported by the lack of effect of the structural analogues of GS and TA47 (daidzein and TA1) on insulin secretion.

In conclusion, the results from our experiments indicate that increased tyrosine phosphorylation per se is not required for glucose-stimulated insulin secretion, nor does an increase in the tyrosine phosphorylation state, as seen with PV, substantially stimulate insulin secretion. Islet PTKs are active under non-stimulatory conditions and our results suggest that they play a permissive role in the insulin secretory process by maintaining a regulatory protein(s) in a tyrosine-phosphorylated state. A likely candidate is a subunit of the VDCC, which would allow $\mathrm{Ca}^{2+}$ influx only when tyrosine phosphorylated. Although we do not at present have any direct evidence for the regulation of VDCCs by tyrosine phosphorylation, both $\alpha_{1}$ and $\beta$ VDCC subunits, which are expressed in islets (Ihara et al. 1995), may be regulated by protein phosphorylation by serine/threonine kinases (Campbell et al. 1988). In addition, the available protein sequence information for the $\beta$ cell VDCC $\alpha$ subunit indicates that it contains several tyrosine residues with acidic residues at positions $\mathrm{N}$-terminal to the tyrosine (Ihara et al. 1995) indicative of a PTK recognition site (Songyang \& Cantley 1995).

\section{ACKNOWLEDGEMENTS}

This work was funded by grants from the Wellcome Trust (grant number 039057), the Medical Research Council and the British Diabetic Association. We thank Clare Hunton for her excellent technical assistance.

\section{REFERENCES}

Brelje TC, Parsons JA \& Sorenson RL 1994 Regulation of islet $\beta$-cell proliferation by prolactin in rat islets. Diabetes $\mathbf{4 3}$ 263-273.

Campbell KP, Leung AT \& Sharp AH 1988 The biochemistry and molecular biology of the dihydropyridine-sensitive calcium channel. Trends in Neuroscience 11 425-430.

Gey GO \& Gey MK 1936 The maintenance of human normal cells in continuous culture. Preliminary report: cultivation of mesoblastic tumors and normal cells and notes on methods of cultivation. American Fournal of Cancer 27 45-76.

Harbeck MC, Louie DC, Howland J, Wolf BA \& Rothenberg PL 1996 Expression of insulin receptor mRNA and insulin receptor substrate 1 in pancreatic islet $\beta$-cells. Diabetes 45 711-717.

Ihara Y, Yamada Y, Fujii Y, Gonoi T, Yano H, Yasuda K, Inagaki N, Seino Y \& Seino S 1995 Molecular diversity and functional characterization of voltage-dependent calcium channels (CACN4) expressed in pancreatic $\beta$-cells. Molecular Endocrinology 9 121-130.

Jancic D \& Wollheim CB 1992 Islet cell metabolism is reflected by the MTT (tetrazolium) colorimetric assay. Diabetologia 35 482-485.

Jonas JC \& Henquin JC 1996 Possible involvement of a tyrosine kinase-dependent pathway in the regulation of phosphoinositide metabolism by vanadate in normal mouse islets. Biochemical fournal 315 49-55.

Jonas JC, Plant TD, Gilon P, Detimary P, Nenquin M \& Henquin JC 1995 Multiple effects and stimulation of insulin secretion by the tyrosine kinase inhibitor genistein in normal mouse islets. British Fournal of Pharmacology 114 872-880.

Jones PM, Stutchfield J \& Howell SL 1985 Effects of $\mathrm{Ca}^{2+}$ and a phorbol ester on insulin secretion from islets of Langerhans permeabilised by high voltage discharge. FEBS Letters 191 102-106.

Jones PM, Salmon DMW \& Howell SL 1988 Protein phosphorylation in electrically permeabilised islets of Langerhans: effects of $\mathrm{Ca}^{2+}$, cyclic AMP, a phorbol ester and noradrenaline. Biochemical fournal 254 397-403.

Jones PM, Mann FM, Persaud SJ \& Wheeler Jones CPD 1993 Mastoparan stimulates insulin secretion from pancreatic $\beta$-cells by effects at a late stage in the secretory pathway. Molecular and Cellular Endocrinology 94 97-103.

Kanaka-Gantenbein C, Dicou E, Czernichow P \& Scharfmann R 1995 Presence of nerve growth factor and its receptors in an in vitro model of islet cell development: implication in normal islet morphogenesis. Endocrinology 136 3154-3162.

Konrad RJ, Dean RM, Young RA, Billings PC \& Wolf BA 1996 Glucose-induced tyrosine phosphorylation of p125 in $\beta$ cells and pancreatic islets. Fournal of Biological Chemistry 271 24179-24186.

Öberg-Welsh C \& Welsh M 1995 Cloning of BSK, a murine $F R K$ homologue with a specific pattern of tissue distribution. Gene 152 239-242.

Öberg C, Waltenberger J, Claesson-Welsh L \& Welsh M 1994 Expression of protein tyrosine kinases in islet cells: possible role of the Flk-1 receptor for $\beta$-cell maturation from duct cells. Growth Factors 10 115-126.

O'Dell TJ, Kandel ER \& Grant SGN 1991 Long-term potentiation in the hippocampus is blocked by tyrosine kinase inhibitors. Nature 353 558-560.

Ohno T, Kato N, Ishii C, Shimizu M, Ito S, Tomono S \& Kawazu S 1993 Genistein augments cyclic adenosine 3'5'-monophosphate (cAMP) accumulation and insulin release in MIN6 cells. Endocrine Research 19 273-285.

Otonkoski T, Cirulli V, Beattie GM, Mally MI, Soto G, Rubin JS \& Hayek A 1996 A role for hepatocyte growth 
factor/scatter factor in fetal mesenchyme-induced pancreatic $\beta$-cell growth. Endocrinology 137 3131-3139.

Persaud SJ \& Jones PM 1995 Inhibition of glucose-stimulated insulin secretion by Ro 31-8220, a protein kinase C inhibitor. Endocrine 3 285-289.

Persaud SJ, Jones PM \& Howell SL 1992 The role of protein kinase C in insulin secretion. In Nutrient Regulation of Insulin Secretion, pp 247-269. Ed P Flatt. London: Portland Press.

Persaud SJ, Jones PM \& Howell SL 1994 Involvement of protein kinases in the regulation of insulin secretion. In Insulin Secretion and Pancreatic B-cell Research, pp 251-256. Eds PR Flatt \& S Lenzen. London: Smith-Gordon.

Persaud SJ, Wheeler-Jones CPD \& Jones PM 1996 The mitogen-activated protein kinase pathway in rat islets of Langerhans: studies on the regulation of insulin secretion. Biochemical Fournal 313 119-124.

Rothenberg PL, Willison LD, Simon J \& Wolf BA 1995 Glucose-induced insulin receptor tyrosine phosphorylation in insulin-secreting $\beta$-cells. Diabetes 44 802-809.

Sekine N, Ullrich S, Regazzi R, Pralong WF \& Wollheim CB 1996 Postreceptor signaling of growth hormone and prolactin and their effects in the differentiated insulin-secreting cell line, INS-1. Endocrinology 137 1841-1850.

Sorenson RL \& Stout LE 1995 Prolactin receptors and JAK2 in islets of Langerhans: an immunohistochemical analysis. Endocrinology 136 4092-4098.
Sorenson RL, Brelje TC \& Roth C 1994 Effect of tyrosine kinase inhibitors on islets of Langerhans: evidence for tyrosine kinases in the regulation of insulin secretion. Endocrinology 134 1975-1978.

Songyang Z \& Cantley LC 1995 Recognition and specificity in protein tyrosine kinase-mediated signalling. Trends in Biochemical Sciences 20 470-475.

Tazi A, Le Bras S, Lamghitnia HO, Vincent JD, Czernichow P \& Scharfmann R 1996 Neurotrophin-3 increases intracellular calcium in rat insulin-secreting cell lines through its action on a functional TrkC receptor. Fournal of Biological Chemistry 271 10154-10160.

Verspohl EJ, Tollkuhn B \& Kloss H 1995 Role of tyrosine kinase in insulin release in an insulin secreting cell line (INS-1). Cellular Signalling 7 505-512.

Young SW, Poole RC, Hudson AT, Halestrap AP, Denton RM \& Tavare JM 1993 Effects of tyrosine kinase inhibitors on protein kinase-independent systems. FEBS Letters 316 $278-282$.

Zhang A, Gao ZY, Gilon P, Nenquin M, Drews G \& Henquin JC 1991 Vanadate stimulation of insulin release in normal mouse islets. Fournal of Biological Chemistry 266 21649-21656.

REVISED MANUSCRIPT RECEIVED 23 June 1998 